\section{Non-Interest Income and Profitability in Private Banking. Evidence from Liechtenstein}

\author{
Konrad Andrzejuk \\ European Business Institute Foundation \\ kmandrzejuk@gmail.com
}

\begin{abstract}
Purpose - The aim of this article is to present results of research on the relation between noninterest income and bank's profitability for Liechtenstein banks specialized in private banking. Design/Methodology/Approach - The study examines 12 Liechtenstein banks specialized in private banking and wealth management services in the period from 2014 to 2016 . Example of Liechtenstein has been chosen as the country is a significant European private banking centre. Data used in the research come from financial statements published by the banks. The relationship between profitability, presented as return on equity (ROE) and return on assets (ROA), and noninterest to interest income ratio has been examined by Pearson correlation coefficient.

Findings - Results show a negative correlation between non-interest to interest income ratio and ROA. No relevant correlation had been found between non-interest to interest income ratio and ROE.

Originality/Value - Most of the researchers investigating the relation between non-interest income and profitability of banks show opposite results to those presented in this paper. Available studies are concentrated on markets dominated by retail and corporate banking services generating mainly interest income. This paper treats the problem of non-interest income's relation to banks' profitability from the perspective of private banking, a specific branch of financial services focused on services generating earnings which are not based on interest-based products.
\end{abstract}

Article type - Research paper.

Keywords - non-interest income, private banking, profitability, ROA, ROE

\section{Introduction}

Traditional role of bank acting as intermediary between deposits' holders and borrowers determines interest as the main source of bank income. However, in recent decades banks have significantly developed range of services and products offered, which resulted in diversification of their income. In accordance with the theory of finances, such a trend should have a positive impact on banks' stability and lead to lower risk level of the bank activity. Nevertheless, several studies show, that high level of non-interest income increases risk, as in comparison with interest income it is usually more volatile and depends significantly on external factors (DeYoung, Roland, 2001; Demirgüç-Kunt, Huizinga, 2010). Studies on determinants of banks' profitability very often examine non-interest income among other internal factors, however, there is still no unanimous answer to the

\section{Non-Interest}

Income and

Profitability in

Private Banking.

Evidence from

Liechtenstein

\section{Q}

International Journal of Synergy and Research

Vol. 6, 2017 pp. $175-182$ 
IJSR

6

question about influence of non-interest income into profitability and risk level of bank as many studies bring opposite results.

Among financial institutions with high share of non-interest income are banks specialized in private banking services, as serving wealthy clients, they sell mainly wealth management services generating fee-based income. In addition, private banks, especially these operating in off-shore banking centres, often observe relatively high share of income from payment transactions fees. Birchler et al. (2015) expose in their study non-interest income as characteristic factor for banks specialized in private banking, selecting for their studies on private banking, entities which not only show observable strategic focus on private banking, but also generate more than one third of their total revenues by fees and commissions.

In this paper, relation between non-interest income and profitability of Liechtenstein banks will be examined. The aim of the investigation is to answer the question, if noninterest income has influence on performance of banks specialized in private banking, as most studies examining such relationship is focused on universal banking. Sample of Liechtenstein was chosen for the investigation, as this country is one of the most important European private banking centres. Liechtenstein banks are almost totally oriented towards private banking. Local market of retail banking services is practically covered by only one financial institution [1], while all other banks are focused on crossborder clients looking for an off-shore financial centre and offering private banking and wealth management services.

\section{Liechtenstein banking sector}

Principality of Liechtenstein with the area of $160 \mathrm{~km}^{2}$ and population of nearly 38000 is one of European mini-states. At the same time, it enjoys one of the highest GDP per capita in the world. In accordance with UN statistics, Liechtenstein's GDP per capita as of 2015 reached USD 169 492, which was the highest value among countries participating in the research. The principality is commonly considered to be one of the European financial centres. Significance of banking sector in Liechtenstein can be proved by the fact that financial services contribute to the national economy generating $24 \%$ of country's GDP as of 2013 (Liechtenstein in Zahlen, 2017). At the end of 2016, 14 fully licensed Liechtenstein banks, regulated by Financial Market Authority (FMA), managed client assets of CHF 234.8 billion, which was equal to more than $3500 \%$ of country's GDP. In the same year, Liechtenstein banks generated earnings before taxation at the level of CHF 474.1 million (Liechtenstein Financial Market, 2017). In accordance with $\mathrm{PwC}$ data, $2.1 \%$ of world offshore assets have been managed by Liechtenstein financial institutions as of 2015 (Schilling et al., 2016).

In the last years, Liechtenstein, previously considered as a tax haven, has implemented several regulations which influence the level of bank secrecy. The impulse to regulate international tax cooperation issues was given in 2009 by OECD, which listed Liechtenstein on its "grey list" of countries assessed by Global Forum on Transparency and Exchange of Information against the international standard for exchange of tax information (Beattie, 2012). Since then, the country has become part of several international agreements related to tax issues. Most of them were double taxation 
treaties. In 2014, Liechtenstein and the USA signed the agreement to implement the provisions of the US Foreign Account Tax Compliance Act (FATCA). Liechtenstein is also a party of Automatic Exchange of Information agreement, which makes the country obliged to exchange tax information with almost 100 countries worldwide, starting from January 01, 2018. Several studies predict that implementation of the regulations mentioned above will be a serious challenge for Liechtenstein banking in the near future (Gostomski, Michałowski, 2015).

All the fully licensed Liechtenstein banks offer wealth management and/or private banking services and are mainly oriented to cross-border clients. Most of them offer multi-language client service. Among the products introduced by Liechtenstein banks, there are such specific ones as philanthropic planning or old timer cars collectors' office inspired by the idea of family office. Diagram 1 gives evidence for the non-interest to interest income ratio showing that traditional banking services generating interest income are not a core business of Liechtenstein banks, while in the European Union, they are still the main source of income in the banking sector.

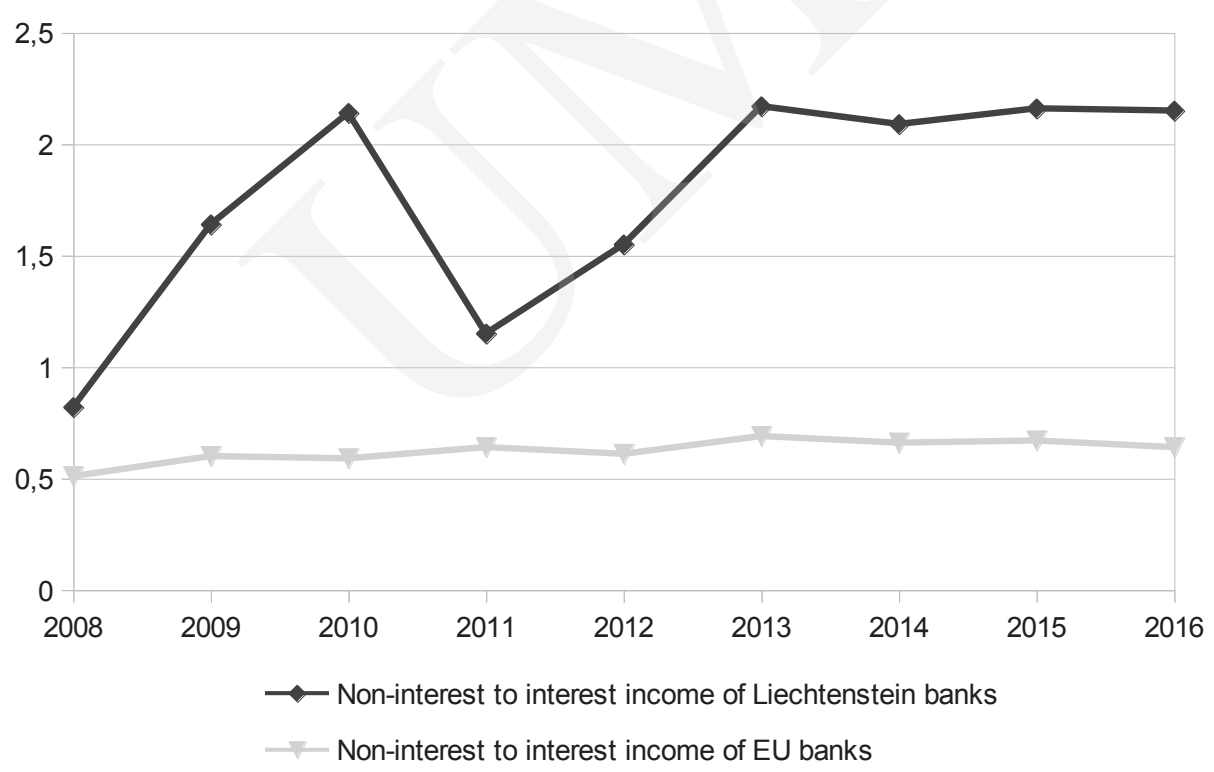

Source: Bankstatistik 2016 (2017), Amt für Statistik, Vaduz; http://ecb.europe.eu

Financial crisis was noticeable also for Liechtenstein bank. In 2008, nearly a 30\% fall in the total amount of assets under management was observed in comparison to 2007.

However, taking into consideration statistics on ROE as an indicator of profitability of Liechtenstein banks, it seems that consequences of the crisis did not try them as severely as in the case of banks from EU countries (see Diagram 2). Even during the crisis, Liechtenstein banking sector was still profitable.
Non-Interest

Income and

Profitability in

Private Banking.

Evidence from

Liechtenstein

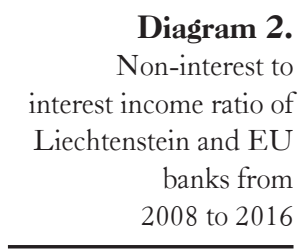

Diagram 2.

interest income ratio of

banks from

2008 to 2016 


\section{IJSR}

6

\section{Diagram 2.}

ROE of Liechtenstein and EU banks (in \%)

from 2008 to 2016

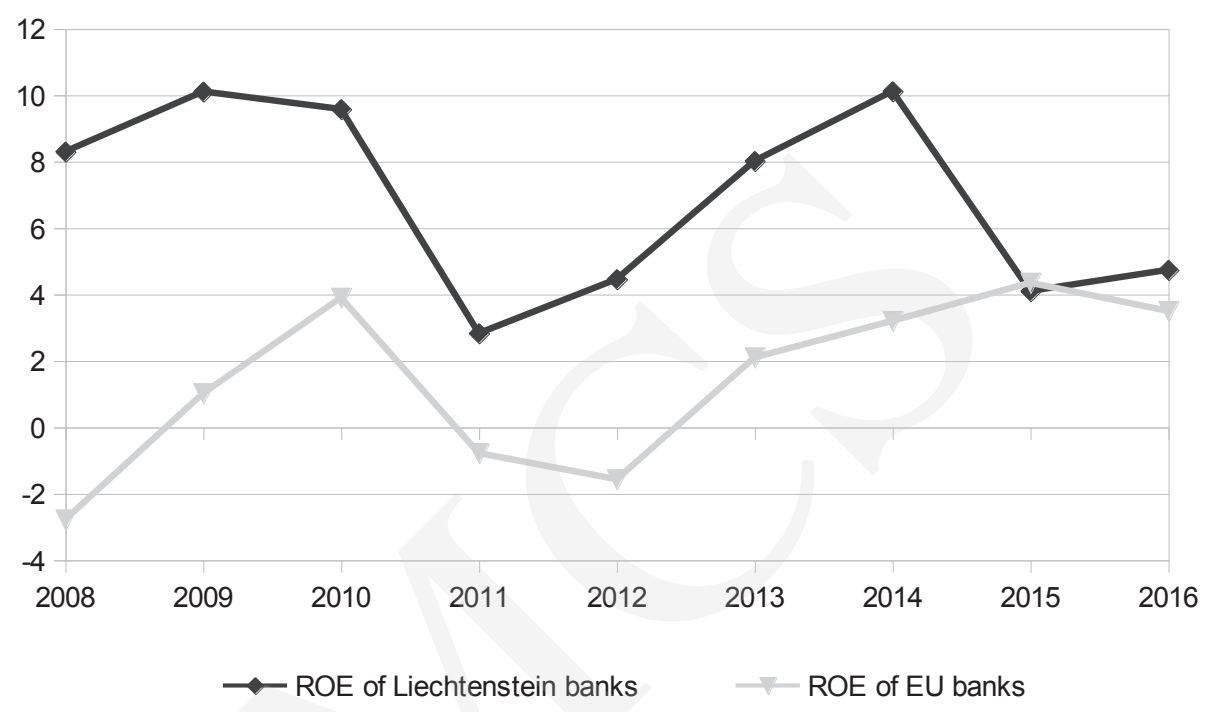

Source: Bankstatistik 2016 (2017), Amt für Statistik, Vaduz; http://ecb.europe.eu

\section{Literature review}

Relationship between non-interest income and profitability of banks has been investigated in many studies, in which banks from different regions were examined. DeYoung and Roland (2001), examining 472 US commercial banks for the period from 1988 to 1995, find that higher fee-based (non-interest) activity, increases banks' profitability but also the level of earnings volatility. Similar results were achieved by the investigation of Demirgüç-Kunt and Huizinga (2010), who examined 1344 banks from 101 countries. They found banks with higher non-interest income share more profitable but also more risky. Gürbüz et al. (2013) investigated 26 Turkish deposit banks for the period 2005-2011 and found, that increase of non-interest income is related to increase of risk-adjusted return on assets.

Dietrich and Wanzenried (2011) examined determinants of Swiss banks' profitability. They find a weak negative relationship between interest income share and profitability. As both types - traditional and wealth-management banks - were included in the studies, the authors considered that margins in asset management, belonging to noninterest income, are generally higher than margins on interest-based products. The same authors in their another study (Dietrich, Wanzenried, 2014), where they investigated determinants of commercial banking profitability in 118 countries, found that in lowincome countries, banks with high share on non-interest income are less profitable, while in countries with middle- and high-income, the tendency is opposite.

Also, Saunders et al. (2014), based on observations of 10341 US banks from 2002 to 2013 , found a positive relationship between non-interest to interest income ratio and profitability. It is especially strong during the crisis. They also underlined the fact, that 
non-interest income is associated with non-core activities of banks and treat non-interest income as an indicator of bank income diversification. Al-Tarawneh et al. (2017) have examined 13 Jordanian banks in the period 2000-2015 and discovered that non-interest income margin (measured as relation of noninterest income to total assets) is positively correlated with ROA.

Interesting results were obtained by Sun et al. (2017), who observed Chinese commercial banks during the period 2007-2013. They identified a negative relationship between non-interest income and banks' profitability, however, the study shows that this tendency is weaker in banks with non-interest income share higher than $16.62 \%$. At the same time, the authors came to the conclusion that growing share of non-interest income, can increase bank's profitability in some cases.

Burgstaller and Cocca (2011) examined 69 banks specialized in private banking and wealth management located in Switzerland and Liechtenstein in the period from 2005 to 2007. They found no significant correlation between fee-income share and bank's profitability calculated as the ratio of the net income from fees and commissions to assets under management. In accordance with investigation's results there is also no relation between fee-income and such indicators as fee margin, cost-income ratio, new net money share or performance, understood as assets under management growth due to investment performance.

\section{Methodology and sample group}

Data analysed in this study come from financial statements of 12 Liechtenstein banks for the period from 2014 to 2016 . The number of observations is 34 in total, as in the case of 2 banks data for 2014 were not available. The observations covered more than 94\% of Liechtenstein banking sector in the examined period, taking into consideration value of total assets.

Sample group is relatively small and also differentiated which is shown in Table 1. Max. total assets for a single observation within the sample group exceeded 30 billion CHF, while the smallest figure was less than 25 million CHF. Such big differences in size of examined banks make them hard to compare within one sample group. On the other hand, the number of banks in Liechtenstein seems to be too small to divide them using size criteria.

\begin{tabular}{lcrrrc}
\hline (Figures in million CHF) & N & Mean & \multicolumn{1}{c}{ SD } & Min. & Max. \\
\hline Net profit & 34 & 33.28 & 87.86 & -4.07 & 492.15 \\
\hline Total assets & 34 & 5102.83 & 9005.54 & 24.88 & 30692.71 \\
\hline Equity & 34 & 486.74 & 866.19 & 13.15 & 2852.95 \\
\hline Interest income & 34 & 26.42 & 44.12 & 0.06 & 167.89 \\
\hline Non-interest income & 34 & 65.01 & 111.27 & 0.97 & 421.91 \\
\hline Equity/Assets (\%) & 34 & 12.97 & 11.71 & 2.68 & 58.94 \\
\hline
\end{tabular}

Source: Own elaboration.
Non-Interest

Income and

Profitability in

Private Banking.

Evidence from

Liechtenstein 


\section{IJSR}

6

Table 2.

R-Pearson correlation of profitability indicators (ROA and ROE) and N/Int. Significance $\mathrm{p}$-value in brackets
In the study, the following two indicators of banks' profitability were used:

- $\mathrm{ROA}=$ return on assets calculated as profit after taxation divided by total assets,

- $\mathrm{ROE}=$ return on equity calculated as profit after taxation divided by shareholders' equity.

In order to measure non-interest income's share, the following indicator was used: $\mathrm{N} /$ Int $=$ non-interest to interest income ratio. Such a ratio has been used previously in several studies (i.a. Saunders et al., 2014). Non-interest income consists of income from commissions and fees, financial transactions, current earnings from securities and other ordinary income.

The relationship between profitability and non-interest income was examined by Pearson correlation coefficient.

\section{Results and discussion}

Results presented in Table 2 show negative correlation of ROA and N/Int with high level of significance $(\mathrm{p}<0.001)$. Negative relationship between ROE and N/Int is weak and statistically non-significant. Taking into consideration a relatively small sample, these results should be approached and interpreted with caution. Nevertheless, lower profitability of examined banks with higher non-interest to interest income ratio is observable in the timeframe covered by this study.

\begin{tabular}{lccc}
\hline & N/Int & ROA & ROE \\
\hline N/Int & & $-0.60^{*}$ & -0.26 \\
& & $(0.000)$ & $(0.138)$ \\
\hline \multirow{2}{*}{ ROA } & $-0.60^{*}$ & & $0.79^{*}$ \\
& $(0.000)$ & & $(0.000)$ \\
\hline \multirow{2}{*}{ ROE } & -0.26 & $0.79^{*}$ & \\
& $(0.138)$ & $(0.000)$ & \\
\hline
\end{tabular}

* means significance at the level of $\mathrm{p}<0.001$

Source: Own elaboration.

Relation between non-interest to interest income ratio and ROE shows a weak negative, but statistically non-significant correlation and cannot be confirmed by results of the research. Equity/assets ratio for Liechtenstein banks is generally high $-12.97 \%$ for the examined sample, but also highly differentiated as Table 1 shows. Also, correlation of ROA and ROE, although relatively strong, seems to show big differences in the level of Liechtenstein banks' capitalization. It makes ROA a more reliable indicator of banks profitability as the level of assets is closely related to the bank's current situation.

Although most studies find positive relation of non-interest income and profitability indicators, Burgstaller and Cocca (2011) investigating profitability, efficiency and growth of private banking sector from Switzerland and Liechtenstein do not come to similar conclusions and do not find a significant relation between fee-income and profitability of bank, measured as relation of net income from fees and commissions to assets under management. It is worth mentioning that their study does not include 
small banks (assets under management below CHF 1 billion) as well as 2 big banks. Additionally, the study of Burgstaller and Cocca (2011) examines banks in the period just before the financial crisis, while post-crisis reality created considerable pressure on a reduction of management fees on investments products, which could make wealth management services less profitable (see Fabozzi et al., 2010). Finally, there should be mentioned that non-interest income, apart from fees and commissions, also consists of financial transactions' earnings, current earnings from securities and other ordinary income, which are not result of the core activity of banks specialized in private banking.

It was already mentioned that non-interest income is considered to be an indicator of banks' income diversification. Most studies examining this problem show that banks with higher share of non-interest income are more profitable. However, opposite results in case of banks specialized in private banking should not be surprising. Non-interest income is the main source of such banks' earnings, as it is generated by its core business. For that reason, in case of banks specialized in private banking and wealth management, high share of non-interest income can be interpreted as an indicator of insufficient diversification of income sources. It seems that bigger banks, which can benefit from economy of scale, are more profitable and, at the same time, they can easier diversify their income sources, while developing lending activity, which plays an important role in private banking as well and generates interest earnings. Assets structure of small banks, active in private banking, usually allows them to benefit only from traditional banking products in limited degree only.

\section{Conclusions}

High share of earnings coming from non-interest products in total bank's income is one of the characteristic indicators for private banking. Positive relation between profitability and non-interest income was observed in many studies. Their authors usually claim that higher share of non-interest income is related to offering wealth-management products, which are generally more profitable than standard bank products based on interest. Noninterest income also accompanies diversification of income sources, which generally favours higher profitability.

This study shows a negative correlation of non-interest income and ROA. Taking into consideration the fact that standard private banking and wealth management products generate mainly non-interest income, the results of this study seem to confirm the thesis that diversification of income sources increases profitability. Nevertheless, as in the literature, the influence of non-interest income on bank's profitability is still discussed, we can conclude that it can depend not only on bank's type and specialization but also on other factors, like geographical situation or core market.

\section{References}

Al-Tarawneh, A., Abu Khalaf, B., Al Assaf, G. (2017). Noninterest Income and Financial Performance at Jordanian Banks. International Journal of Financial Research, vol. 8, no. 1, pp. $166-171$.

Bankstatistik, 2016 (2017). Amt für Statistik, Vaduz.

\author{
Non-Interest \\ Income and \\ Profitability in \\ Private Banking. \\ Evidence from \\ Liechtenstein
}


IJSR

6

Beattie, D. (2012). Liechtenstein. A Modern History, Van Eck Verlag, Triesen.

Birchler, U., Bührer, C., Hegglin, R., Reichenecker, M. (2015). The International Private Banking Study 2015, Department of Banking and Finance, University of Zurich, Zurich

Burgstaller, J., Cocca, T. (2011). Profitability, Efficiency and Growth in the Private Banking Industry: Evidence from Switzerland and Liechtenstein. Financial Markets and Portfolio Management, vol. 25, pp. 75-93.

Demirgüç-Kunt, A., Huizinga, H. (2010). Bank Activity and Funding Strategies: The Impact on Risk and Returns. Journal of Financial Economics, vol. 98, pp. 626-650.

DeYoung, R., Roland, K. (2001). Product Mix and Earnings Volatility of Commercial Banks: Evidence from Degree of Total Leverage Model. Journal of Financial Intermediation, no. 10 , pp. 54-84.

Dietrich. A., Wanzenried, G. (2011). Determinants of Bank Profitability Before and During the Crisis: Evidence from Switzerland. Journal of International Financial Markets, Institutions and Money, vol. 31, no. 3, pp. 307-327.

Dietrich, A., Wanzenried, G. (2014). The Determinants of Commercial Banking Profitability in Low-, Middle-, and High-Income Countries, The Quarterly Review of Economics and Finance, vol. 54, no. 3, pp. 337-354.

Fabozzi, F., Focardi, S., Jonas, C. (2010). Investment Management after the Global Financial Crisis, Research Foundation of CFA Institute, Charlottesville.

Gostomski, E., Michałowski, T. (2015). Liechtenstein jako gasnący raj podatkowy. Pieniadze $i$ Więź, no. 2, pp. 117-125.

Gürbüz, A., Yanik, S., Aytürk, Y. (2013). Income Diversification and Bank Performance: Evidence from Turkish Banking Sector. Journal of BRSA Banking and Financial Markets, vol. 7, no. 1, pp. 9-29.

Liechtenstein in Zahlen 2017, (2017). Amt für Statistik, Vaduz.

Liechtenstein Financial Market, (2017). Financial Market Authority, Vaduz. Retrieved February 9, 2018 from: https://www.fma-li.li/files/fma/fma-financial-market-liechtenstein-edition -2017.pdf

Saunders, A., Schmid, M., Walter, I. (2014). Non-Interest Income and Bank Performance: Does Ring-Fencing Reduce Bank Risk?, University of St. Gallen, School of Finance Research Paper no. 2014/17. Retrieved February 9, 2018 from: http://ux-tauri.unisg.ch/RePEc/usg/ sfwpfi/WPF-1417.pdf

Schilling, M., Meier, L., Ecabert, F., Pauli, R., Schneeberger, K. (2016). Private Banking in Switzerland and Liechtenstein: Are Its Days Numbered?, PricewaterhouseCoopers. Retrieved February 9, 2018 from: https://www.pwc.ch/en/publications/2016/privatebanking _ switzerland_liechtenstein_en.pdf

Sun, L., Wu, S., Zhu, Z., Stephenson, A. (2017). Noninterest Income and Performance of Commercial Banking in China. Scientific Programming, no. 2, article no. 7. Retrieved February 9, 2018 from: https://www.hindawi.com/journals/sp/2017/4803840/

\section{Notes}

[1] LLB (Liechtensteinische Landesbank) established in 1861, with State of Liechtenstein as majority shareholder, is the only bank of the country strongly focused on retail banking. The Bank declares, that more than $90 \%$ of Liechtenstein's residents are its retail clients. Nevertheless, more than $40 \%$ of the bank's revenue is generated by its private banking department. 